\title{
An Uncompleted Federal Government Infrastructure (Project): An Anathema to Economic Diversification
}

Ifeoma Christy Mba, Emmanuel Ikechukwu Mba, Winnie Ogonna Arazu, and Oluwaseun Alade

\section{ABSTRACT}

\begin{abstract}
Infrastructure development is the hub of economic diversification, for any nation to grow economically; it must be seriously dependent on its iron and steel development. The construction of the Ajaokuta iron and steel industry can be dated and traced to the year 1979 and as of 1994, the project was near completion with $98 \%$ of the project almost completed. As of 2018, the project is yet to be completed. The gap between 1979 through 1994 to 2018 gives the Nation a whole cause to worry thereby implying whether the delay in the work is due to the incompetency of the contractors in question or is it due to bad governance and suspected looting. This paper, therefore, applies the use of the popular Critical Path Method (CPM) in monitoring the progress of the yet-to-be-completed Ajaokuta project focusing on its possible network diagram, earliest and latest time of completion.
\end{abstract}

Keywords: Ajaokuta, critical path method, diversification.

\author{
Submitted : May 07, 2021 \\ Published : June 08, 2021 \\ ISSN: $2507-1076$ \\ DOI: $10.24018 /$ ejbmr.2021.6.3.882 \\ I. C. Mba* \\ Department of Economics, University of \\ Nigeria, Nsukka, Enugu Nigeria. \\ (e-mail: ifeoma.mba ${ }^{\circledR}$ unn.edu.ng) \\ E. I. Mba \\ Department of Statistics, University of \\ Nigeria, Nsukka, Enugu Nigeria. \\ (e-mail: emmanuel.mba ${ }^{@}$ unn.edu.ng) \\ W. O. Arazu \\ Department of Economics, University of \\ Nigeria, Nsukka, Enugu Nigeria. \\ (e-mail: winnie.arazu@ ${ }^{\circledR}$ unn.edu.ng) \\ O. Alade \\ Department of Economics, University of \\ Nigeria, Nsukka, Enugu Nigeria. \\ (e-mail: oluwaseun.alade ${ }^{@}$ unn.edu.ng) \\ *Corresponding Author
}

\section{INTRODUCTION}

In any progressive nation, the iron and steel industry is regarded as the hub of development, this is because, in developed nations, the industry is known for its ability to control the world and provide job opportunities by the diverse products and services it offers. The iron and steel industry is very important and that is why a steel company based in South Korea had an inscription on the entrance that read "A nation that controls Iron controls the world" - Pohang Steel Company Ltd. In Nigeria, the sustenance of the iron and steel industry and its production has not been actualized since every effort to make the iron and steel industry in Nigeria the envy of other countries. Actions had been put in place and efforts on how to start production in the Ajaokuta iron and steel industry had proved abortive. Can the Vision 20:2020 Agenda of the Nigerian Federal Government be sustained when there had always been a mass influx in the name of importation of steel and iron products into the giant of Africa? Nigeria has done well in many sectors of the economy, sectors such as oil and gas, cement manufacturing, and telecommunication [1], most recently, Nigeria has also made a huge strive or impact on the entertainment industry.

The thrust of these articles is on why the Ajaokuta Iron and Steel project is not yet completed, the project was $98 \%$ near completion since 1994 and to date, it is not fully completed. What could be the problem? Is the problem due to its management or due to inexperienced contractors? or is it a case of corruption and diversion of public funds? Whatever is the case, the iron and steel industry in Ajaokuta is not in full swing and not functional. The structure is there, the equipment that cost billions of naira are there, the manpower resources are there also, so what is the problem? To answer the above questions, the researcher decided to employ the critical path method analysis, looking at the float and nonfloat projects, the critical and non-critical project, the earliest and latest time of completion for the project, thus, the assumption that the problem that is facing them is not a structural or building problem but rather the problem of making her first new product production. Firstly, there would be a project network that would include predecessor projects or activities, where one can see what project must be concluded before another one begins or even better still see projects that can run concurrently.

\section{BRIEF Historical BACKGROUND OF THE SteEl Plants IN NIGERIA}

The major task of the iron and steel industries in Nigeria was a deliberate act of bringing development to our doorstep, it was a task that involved a well-structured process in achieving well-articulated and itemized objectives. Articulated objectives that were aimed at providing a solid base of industrial technologies and their associated 
development. The articulated objectives were also fashioned in achieving a kind of modern technology that would not only promote development but also create job opportunities and bring about the acquisition of skills and expertise.

In 1958, planning was put in place to establish the Nigerian Steel Industry. The services of different international organizations and also many consulting firms were employed and commissioned at a different period to make feasibility studies on how the steel plant should go, all these were under the sponsorship and guidance of the Federal Ministry of Industries [2]. In 1971, the Nigerian Steel Development Authority" (NSDA) was the agency established by Decree to actualize the steel plant. The agency worked tirelessly, they carried out a market survey to discover raw material sources and alternative sources of iron-ore and so on [2]. Between the years 1975-1980, a $3^{\text {rd }}$ national development plan was erected under decree number 60 of September 1979 and the effect of the decree was to dissolve the Nigerian Steel Development Authority (NSDA) and thus establish companies and research institutes to succeed them. The following companies established are the:

1. Ajaokuta steel project, Ajaokuta.

2. Delta steel company Ovwian-Aladja.

3. Jos steel rolling company, Jos.

4. Kastina steel rolling company, Kastina.

5. Oshogbo steel rolling company, Oshogbo.

6. National Iron ore mining company, Itakpe.

7. National steel raw materials exploration agency, Kaduna.

8. National Metallurgical development center, Jos.

9. Metallurgical training institute, Onitsha.

From 2002 to date, an import substitution policy was enacted and the implications from that policy were to reduce product importation so that the domestic production would grow and thus encouraged. Thus from 2002 to 2012, the companies responsible for the importation of steel products are to begin steel production plants installation. The effect of this policy (Backward integration policy of 2002) was felt when the ASC, that is, the Ajaokuta steel company rolling mills were completed before that of the iron and steel making mills. The privatization policy of 1999 was visualized in the 2004-2005 era when they established the National Council on Privatization, the government-owned steel companies were then privatized during this era. The NCP in the same year, in 1999, also established the Bureau of Public Enterprises (BPE), the agencies were to man the sale of the Ajaokuta steel company, the Delta steel company, the National Iron ore Mining Company (NIOMCO), and of course the rail track from Itakpe to Aladja to foreign companies (the Indians). The other buyers were Nigerian investors, who bought the 3 inland rolling mills. The so-called privatization that was carried out wasn't corrupt-free and thus never transparent [3].

Goals, vision, and targets for the steel industries in Nigeria were put in place under the vision 20: 2020 policy. The target was that our dear country shall produce 12.2 million tonnes per annum of steel by the year 2020 and thus, ASC was to produce 5.2 million tonnes, DSC; 2.0 million tonnes, and the remaining was for the private bodies.

Efforts were put in place to boost the domestic steel production, that is why the fiscal year 2001 price tariff for steel policy was established and thus very effective to date.
The tariff increased from $30 \%$ to $65 \%$ for all rolled products and a decrease was seen from $10 \%$ to $5 \%$ for billets.

Import licenses were given to only companies who were interested in promoting and boosting the production of domestic steel. The first contractors to build the rolling mills in Ajaokuta steel were the Russian Contractors, the Russian contractors imported billets from Ukraine and thus started using them before they embarked on the steel plant, and to date, it was never completed [1].

Past authors such as [1], [4], [5] believed that the Ajaokuta project was 98\% near completion as of December 1994.

It is pertinent to think that every effort to bring the steel sector to life proved abortive and thus, there had always been a failure in reviving the Iron and steel industry in Nigeria. From the above brief history, it can be seen that the problem is for production to start in Ajaokuta. Below is a table that shows those companies that have tried running the Ajaokuta steel company.

TABLE I: COMPANIES THAT HAVE ATtemPted To InSTALl THE Plant OR

\begin{tabular}{|c|c|c|}
\hline \multicolumn{3}{|c|}{ OPERATE AJAOKUTA STEEL COMPLEX } \\
\hline Era & $\begin{array}{c}\text { EPC contractor } \\
(\text { Lead })\end{array}$ & Achievements (work done) \\
\hline $\begin{array}{c}\text { 18 September } \\
1979-1999\end{array}$ & $\begin{array}{l}\text { Tiaj prom export } \\
\text { (TPE), Russia }\end{array}$ & $\begin{array}{l}\text { Facilities installed include; } \\
\text { iron plant, steel plant, power } \\
\text { plant, rolling mills }\end{array}$ \\
\hline $\begin{array}{l}13 \text { October } \\
2003-2004\end{array}$ & Solgas Energy, USA & No visible progress \\
\hline 2001-2003 & TPE & Project was incomplete \\
\hline $\begin{array}{l}\text { August 2004- } \\
2013\end{array}$ & $\begin{array}{c}\text { Global infrastructure } \\
\text { Holding Ltd (GIHL) } \\
\text { member of Ispat } \\
\text { industries Ltd, India }\end{array}$ & $\begin{array}{l}\text { November } 2004 \text { rolling plant } \\
\text { began operation and by } 2006 \\
\text { BF started working. Steel } \\
\text { products were produced and } \\
\text { even exported to Ghana and } \\
\text { Sierra Leone }\end{array}$ \\
\hline
\end{tabular}

Source: table curled from [1].

Table II is another table that shows installed materials or facilities at the Ajaokuta steel complex.

\section{LITERATURE REVIEW}

The concession policy in the ASC was looked into by [8]which many believed would be the key to development but with the crisis in ASC, the policy became a chimera or an illusion to development. He looked at the correlation between the concession and the plight of the company's staff. He found out that Ajaokuta steel company (ASC) which was supposed to be the bedrock of development in Nigeria was o ghost of itself [8]. Another researcher saw that the production of steel was achieved from Itakpe iron ore which is locally available and thus produced in the Delta Steel Direct Reduction -Electric Arc Furnace Plant. Although the gauge was unsuitable for its low quality made it not suitable in Ajaokuta because Ajaokuta was fashioned for the blast furnace, thus, the low quality was rather used in Delta [9]. An author viewed the development of Japan and how they expanded, they expanded their steel industry from around 1857 to date. He believed that Nigeria should learn from them, employ their services so that our steel industry can be fast-tracked, or better still that the Nigerian government should look for ways to cooperate with the Japanese and also explore possibilities [7]. Ohimain viewed the challenges of the domestic iron and steel production in Nigeria, with ASC and DSC (Aladja) and the 3 rolling mills in Oshogbo, Jos, and 
Kastina. These projects according to him were supposed to have kicked off but did not because of several factors such as political, technical, logistical, and managerial challenges. So, the publicly-owned iron and steel company folded up because of the factors and the private ones couldn't sustain herself because of lack of raw materials [1]. For the iron and steel industry to be sustained, there should be a strong vehicle for industrial transformation because it has been stagnant for a very long time [2]. A group of researchers also opined that the so-called vision 20:2020 cannot be realized because the iron and steel industry in Nigeria lacks sustenance [2]. The Ajaokuta steel as viewed by [10] has not manufactured a single product or better still a single sheet of steel even as billions of naira has been pumped into the project, he went further in advising the Federal government to take the matter as a serious one and that the expert's suggestions that the services of foreigners shouldn't be employed any longer but we should look inwardly for the breakthrough. He also added that the plants are there, the brains are here, the technologies are within, there could be an upgrade if there is need for it [10]. The gap in the study is on the fact that literatures reviewed did not actually address the issue on ground. The issue of looking at duration allocated for an activity, the earliest time and latest time, the slack or float activity, the critical and non-critical projects.

TABLE II: FACILITIES INSTALLED AT THE AJAOKUTA STEEL COMPLEX

\begin{tabular}{|c|c|c|c|}
\hline $\mathrm{S} / \mathrm{N}$ & Type & Plant unit & Capacity (p.a) \\
\hline \multirow[t]{4}{*}{1} & Rolling mills & Light section mill $(320 \mathrm{~mm})^{\mathrm{a}}$ & 400,000 tonnes $^{\mathrm{a}}$ \\
\hline & & Wire rod mill $(150 \mathrm{~mm})^{\mathrm{b}}$ & 130,000 tonnes $^{\mathrm{b}}$ \\
\hline & & Billet mill $(900 \mathrm{~mm} / / 630 \mathrm{~mm} \text { semi continuous })^{\mathrm{c}}$ & 795,000 tonnes $^{\mathrm{c}}$ \\
\hline & & Medium section and structural mill $(700 \mathrm{~mm})^{\mathrm{d}}$ & 560,000 tonnes $^{\mathrm{d}}$ \\
\hline \multirow[t]{9}{*}{2} & Iron and & Blast furnace ${ }^{a}$ & \\
\hline & steel mills & Sintering plant ${ }^{\mathrm{b}}$ & \\
\hline & & Raw materials preparation and handling & $2,640,000$ tonnes $^{\mathrm{c}}$ \\
\hline & & system $^{c}$ & 43,400 tonnes $^{\mathrm{d}}$ \\
\hline & & Alumina-silicate refractory plant ${ }^{\mathrm{d}}$ & 8,800 tonnes $^{\mathrm{e}}$ \\
\hline & & Tar-bonded dolomite refractory plant ${ }^{\mathrm{e}}$ & 91,000 tonnes $^{\mathrm{f}}$ \\
\hline & & Lime plant ${ }^{\mathrm{f}}$ & 440,000 tonnes $^{\mathrm{g}}$ \\
\hline & & Coke-oven battery ( 1 of 2 completed $)^{\mathrm{g}}$ & $36,000 \mathrm{~m}^{2} / \mathrm{hr}^{\mathrm{h}}$ \\
\hline & & Oxygen plant ${ }^{\mathrm{h}}$ & \\
\hline \multirow[t]{6}{*}{3} & Engineering & Foundry and pattern making shop ${ }^{a}$ & 7,000 tonnes $^{\mathrm{a}}$ \\
\hline & works & Forge and fabrication shop ${ }^{\mathrm{b}}$ & 8,800 tonnes $^{\mathrm{b}}$ \\
\hline & complex & Machine and tools shops ${ }^{\mathrm{c}}$ & 19,000 tonnes $^{\mathrm{c}}$ \\
\hline & & Power equipment repair shop ${ }^{\mathrm{d}}$ & Repair of electric motors/generators etc. ${ }^{\mathrm{d}}$ \\
\hline & & Rubberizing shop ${ }^{\mathrm{e}}$ & Repair of conveyor belt; manufacturing of seals etc. ${ }^{\mathrm{e}}$ \\
\hline & & Erection base $^{\mathrm{f}}$ & Fabrication/assembly of various structures/components ${ }^{f}$ \\
\hline 4 & Power plant & Thermal & $110 \mathrm{MV}$ \\
\hline
\end{tabular}

Sources: [1], [6], [7].

\section{CRitical Path Method/ CRitical Path Analysis}

The main aim of the CPM is to determine the total duration of a project and thus starting and finishing times are assigned to every activity in the project when duration is assigned to all activities in a project, the actual progress is checked against the scheduled time duration as stipulated in the project plan.

Thus, before one embarks on the preparation of any project, such a person should ascertain first the following important points below:

(i) Completion time of the project in totality.

(ii) Earliest and latest start time of each of the stipulated activities.

(iii) Critical activities and their associated critical path.

(iv) Float available to each activity i.e., how much amount of time is available to an activity that isn't critical such that it won't delay the entire project completion time.

The ultimate thrust in CPM is its ability to construct time schedules for any project it comes across. Thus, in carrying out CPM computations, the following information is necessary and essential:

1. To complete any project, total duration is a necessity.

2. Activities in any project are classified as critical and non-critical.

In other words, critical activities do not give room for scheduling slack while non-critical activities do, so, leeway is allowed in non-critical activities but not allowed for critical.

\section{A. Definition of Terms}

An event is a point in time where activities are terminated, and other activities start. So, in this paper, we refer to the event here as the "node" and these nodes are linked by branches or arcs, these are what constitute a network.

The earliest time of the event and the latest occurrence time of an event, say event $\mathrm{j}$ is the starting and completion time (dates) of the whole project in question.

\section{B. Phases of the CPM Calculations}

The forward is to the earliest occurrence time as it determines the earliest time of occurrence of the events while the backward is to the latest occurrence times, it determines the latest time of occurrence of the event.

In calculating the forward pass or the earliest occurrence times, the initial event which is also referred to as the initial step of the event is set as Zero.

Thus, on a general note, the maximum value that comes from the addition of the preceding event plus its duration gives rise to the earliest time while the minimum value portrays the latest time.

\section{Determination of the Floats}

For total float, $\mathrm{TF}_{\mathrm{ij}}=$ latest time of $\mathrm{j}$ minus earliest time of $\mathrm{i}$ minus the duration for $\mathrm{i}$ and $\mathrm{j}$. 
For the Free Float FF = earliest time j minus earliest time i minus the duration of $\mathrm{i}$ and $\mathrm{j}$.

\section{Red Flagging Rule}

This rule is used mainly for noncritical activities, thus:

1. If $\mathrm{FF}=\mathrm{TF}$, schedule activity anywhere.

2. If $\mathrm{FF}<\mathrm{TF}$, the start of the activity would be delayed relative to the FF but not more than TF.

\section{ANALYSIS}

Let us assume that for the Ajaokuta steel company to resume activities, i.e., production proper, firstly, network analysis would be put up and thus, the duration for each activity would be given, let's assume also that the project as we were told earlier is more than $90 \%$ near completion and what is left to be done is the project of introducing their very first (new) product. Thus, the following activities are itemized as follows:

\begin{tabular}{|c|c|c|}
\hline Activity & Description & $\begin{array}{c}\text { Predecessor } \\
\text { activity }\end{array}$ \\
\hline $\mathrm{A}$ & Develop a plan for the new product & - \\
\hline B & $\begin{array}{l}\text { Questionnaire should be prepared } \\
\text { and sent to the field }\end{array}$ & A \\
\hline $\mathrm{C}$ & $\begin{array}{l}\text { Test run packages and approve } \\
\text { them when necessary }\end{array}$ & $\mathrm{B}$ \\
\hline $\mathrm{D}$ & Unit cost should be approved & $\mathrm{C}$ \\
\hline $\mathrm{E}$ & $\begin{array}{l}\text { Media advertisement schedule and } \\
\text { sales }\end{array}$ & $\mathrm{D}$ \\
\hline $\mathrm{F}$ & $\begin{array}{c}\text { Employees are hired, trained, } \\
\text { manpower needs and production } \\
\text { equipment are designed and } \\
\text { developed }\end{array}$ & $\mathrm{B}, \mathrm{E}$ \\
\hline G & $\begin{array}{l}\text { Installation and arrangement of } \\
\text { production equipment }\end{array}$ & $\mathrm{F}$ \\
\hline $\mathrm{H}$ & $\begin{array}{l}\text { Ordering, receiving and checking of } \\
\text { raw materials }\end{array}$ & G \\
\hline $\mathrm{I}$ & $\begin{array}{c}\text { Repairing and checking of } \\
\text { warehouse space }\end{array}$ & $\mathrm{E}$ \\
\hline $\mathrm{J}$ & $\begin{array}{l}\text { Manufacturing the new product i.e. } \\
\text { First production run }\end{array}$ & $\mathrm{H}, \mathrm{I}$ \\
\hline $\mathrm{K}$ & Conducting Sales meetings & I \\
\hline $\mathrm{L}$ & $\begin{array}{c}\text { Contacting customers and receiving } \\
\text { orders }\end{array}$ & $\mathrm{J}, \mathrm{K}$ \\
\hline M & $\begin{array}{l}\text { Processing orders and sending the } \\
\text { new product }\end{array}$ & $\mathrm{L}$ \\
\hline
\end{tabular}

The network representation of Table III above:

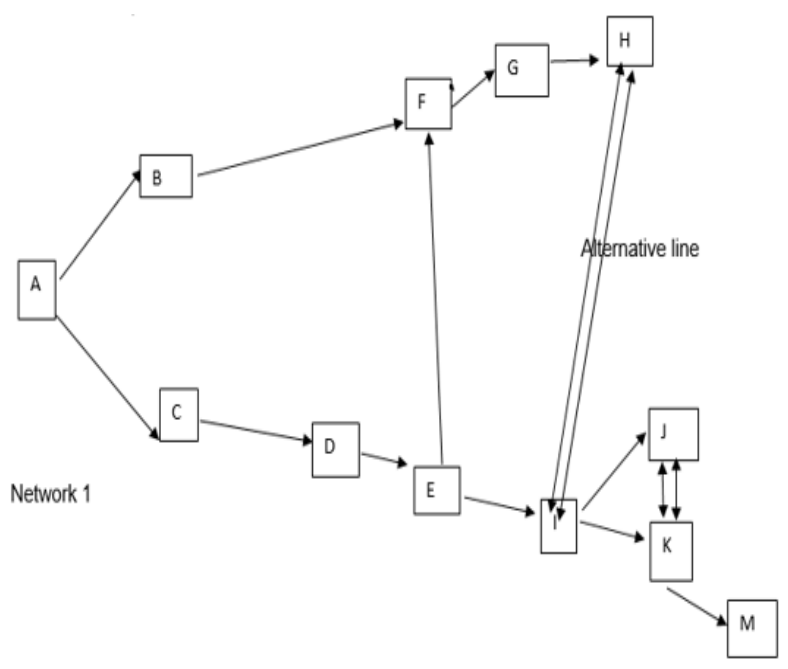

Fig. 1. Network for the Activity Table. Source: Author's graph.
Above, is the network of the production of a new (first) product from the Ajaokuta Steel company. thus, the double arrow with heads on both sides simply means alternative link, that is, node $\mathrm{I}$ and node $\mathrm{H}$; nodes $\mathrm{J}$ and $\mathrm{K}$ are all linked together to bring about the $\mathrm{J}$ and $\mathrm{M}$, respectively.

Let us now assume that the process is merged, and the new network below would thus be used to calculate the earliest time, latest time, and so on.

See the computations and network 2 below:

Calculations for the earliest time:

Set node $1=0$.

For node 2, node $1+$ the duration $(\mathrm{D} 12)=0+5=5$.

For node $3, \max \{$ node $1+\mathrm{D} 13$, node $2+\mathrm{D} 23\}=\max \{0+6$, $5+3\}=8$

For node 4 , node $2+\mathrm{D} 24=5+8=13$.

For node $5, \max \{$ node $3+\mathrm{D} 35$, node $4+\mathrm{D} 45\}=\max \{8$ $+2,13+0\}=13$.

For node $6, \max$ \{node $3+\mathrm{D} 36$, node $4+\mathrm{D} 46$, node $5+$ D56 $\}=\max \{8+11,13+1,13+12\}=25$.

From the above calculations, it can be seen that the project in Ajaokuta steel can be completed in 25 days.

Latest time:

Node 6: set node 6 to equal 25.

For node 5, node $6-$ D56 $=25-12=13$.

For node $4, \min \{$ node $6-\mathrm{D} 46$, node $5-\mathrm{D} 45\}=\min \{25$ $-1,13-0\}=13$.

For node $3, \min \{$ node $6-\mathrm{D} 36$, node $5-\mathrm{D} 35\}=\min \{25$ $-11,13-2\}=11$.

For node $2, \min \{$ node $4-\mathrm{D} 24$, node $3-\mathrm{D} 23\}=\min \{13$ $-8,11-3\}=5$.

For node $1, \min \{$ node $3-\mathrm{D} 13$, node $2-\mathrm{D} 12\}=\min \{11$ $-6,5-5\}=0$.

Any calculations that did not end with zero (0) are not correct and thus should be rechecked. The earliest time and latest time calculations can be seen in network 2 below.

For the critical path, the nodes from start to end is given as 12456 , and the associated critical activities are: $[(1,2),(2,4)$, $(4,5)$, and $(5,6)]$ which automatically equals the duration of the project, i.e., 25 days.

For activity $(4,6)$, it is not critical irrespective that the earliest time of 13 equals its latest time of 13 , and the earliest time of 25 equals the latest time of 25 but the difference which did not satisfy the third criteria for critical assumptions. That is; the 3 conditions necessary for critical activities are:

1. Latest time for activity $i=$ Earliest time for activity $i$.

2. Latest time for activity $\mathrm{j}=$ Earliest time for activity $\mathrm{j}$.

3. The difference between the latest time for activity $\mathrm{j}$ and the latest time for activity $i$, which must equal the difference between the earliest time for activity $j$ and earliest time for activity $i$ which we refer to as the duration i.e., Dij.

The next step is to calculate the Floats for noncritical activities of the network. The table below shows the calculations. 


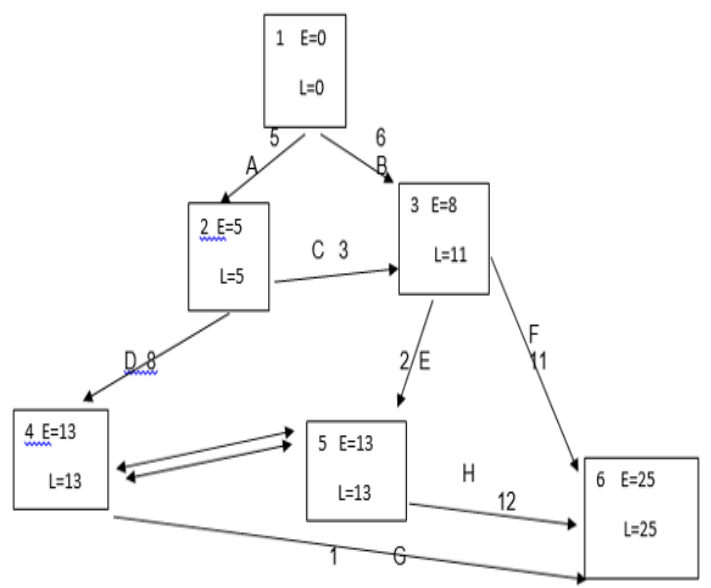

Fig. 2. Network of Earliest and Latest Time. Source: Author's compilation.

\section{TABLE IV: FLOAT FOR NONCRITICAL ACTIVITIES}

\begin{tabular}{cccc}
\hline $\begin{array}{c}\text { Noncritical } \\
\text { activity }\end{array}$ & Duration & Total float (TF) & Free float (FF) \\
\hline $\mathrm{B}(1,3)$ & 6 & $11-0-6=5$ & $8-0-6=2$ \\
$\mathrm{C}(2,3)$ & 3 & $11-5-3=3$ & $8-5-3=0$ \\
$\mathrm{E}(3,5)$ & 2 & $13-8-2=3$ & $13-8-2=3$ \\
$\mathrm{~F}(3,6)$ & 11 & $25-8-11=6$ & $25-8-11=6$ \\
$\mathrm{G}(4,6)$ & 1 & $25-13-1=11$ & $25-13-1=11$ \\
\hline
\end{tabular}

From above Table IV, activities $\mathrm{B}$ and $\mathrm{C}$ are the red flag activities because of $\mathrm{FF}<\mathrm{TF}$. The remaining activities $(\mathrm{E}, \mathrm{F}$, and $\mathrm{G}$ ) have their $\mathrm{TF}=\mathrm{FF}$ and thus it simply means that they can be scheduled anywhere along with the earliest time start and the latest completion times. The red-flagged activity for $\mathrm{B}$ signifies that the $\mathrm{TF}=5$ days, can start as early as time 0 or as late as period 5 but because its FF is 2 days, activity B can start anytime between 0 and 2 and this wouldn't affect the next or succeeding event, i.e. activities $\mathrm{E}$ and $\mathrm{F}$. if for any reason the start time at 2 plus duration should still be less than 5 , what it means is that the project start time should be extended by 2 , so it would no longer be 8 . For activity $C$, the red-flagged activity shows that $\mathrm{FF}=0$ which means that any delay in starting activity $\mathrm{C}$ past its earliest time of 5, must be reflected in an equal delay in the start time of succeeding activities $\mathrm{E}$ and $\mathrm{F}$.

\section{CONCLUSION AND RECOMMENDATION}

From the analysis above as regards Ajaokuta iron and steel company, it is pertinent to note that mismanagement is the greatest problem of that industry. The mismanagement is coupled with corruption. Our concern is on how to diversify the economy but is it possible without removing the spirit of corruption from our society. A project that is almost $100 \%$ since the nineties is what we are still talking about. We could see from the above assumptions that the project can be completed within a month because the problem is not the money but rather the attitude of humans. I recommend that the project should be revisited, and we should use what we have in terms of the brain, resources, and whatever that is within our capacity to see that the Ajaokuta iron and steel industry is totally completed.

\section{REFERENCES}

[1] E. I. Ohimain, 'The Challenge of Domestic Iron and Steel Production in Nigeria', greener J. Bus. Manag. Stud., vol. 3, no. 5, pp. 231-240, 2013.

[2] J. A. Ajayi, M. A. Adegbite, and A. R. Iyanda, 'Sustainable iron and steel production in Nigeria: the Techno-Economic backbone of the national development'. pp. 1-7, 2013.

[3] S. A. Mohammed, 'Privatization of the iron and steel industry in Africa', in 8th international Arab Iron and Steel conference held at Doha, Qatar 17th-19th March, 2008, 2008.

[4] D. Izon, 'The mineral industry of Nigeria', in United States Geological Survey Minerals Book, 1995.

[5] S. A. Mohammed and H. A. Yusuf, 'Ajaokuta steel company Ltd', in African Iron and Steel Development Association, 2004.

[6] S. A. Mohammed, 'Nigeria steel industry-historical development', 2002.

[7] O. Agbu, 'The iron and steel industry and Nigeria's industrialization: exploring cooperation with Japan', 2007.

[8] N. E. Attah, 'Ajaokuta Steel Company of Nigeria and concession : counting the human cost , 2003 - 2010', African J. Econ. Sustain. Dev., vol. 2 , no. 2 , pp. 157-171, 2013.

[9] O. O. Olayebi, 'Steel making experience in the use of Nigerian Iron Ore at the Delta Steel Company, Nigeria', J. Chem. Eng. Mater. Sci., vol. 5, no. 5, pp. 47-62, 2014.

[10] M. A. Krishi, 'How to revive Ajaokuta steel company', Daily Trust Thursday July 19, 2018, 2018. 